\title{
A potential protective mechanism of soya isoflavones against 7,12-dimethylbenz[a]anthracene tumour initiation
}

\author{
Ho Yee Chan ${ }^{1}$ and Lai K. Leung ${ }^{1,2 *}$ \\ ${ }^{1}$ Department of Biochemistry and ${ }^{2}$ Food and Nutritional Sciences Programme, The Chinese University of Hong \\ Kong, Shatin, N.T., Hong Kong
}

(Received 6 November 2002 - Revised 25 March 2003 - Accepted 12 April 2003)

\begin{abstract}
Epidemiological studies indicate that Asian women have a lower breast cancer incidence compared with their counterparts in the West, and the difference has been related to soya consumption. Animal studies have suggested that soya may prevent dimethylbenz[a]anthracene (DMBA)-induced carcinogenesis in the breast. In the present study a cell culture model was developed to address the effect of soya isoflavones on the DMBA-induced DNA damage. DMBA is metabolized into a DNA-attacking moiety by two phase I cytochrome P450 (CYP) enzymes CYP1A1 and CYP1B1. DNA mutation caused by this genotoxic agent is a crucial step in cancer initiation. Substances that interfere with the CYP1 enzyme activities can affect the initiation. In the present study, genistein was found to be an effective inhibitor of recombinant human CYP1A1 and CYP1B1 with $\mathrm{K}_{\mathrm{i}}$ of 15.35 and $0.68 \mu \mathrm{mol} / \mathrm{l}$. The other soya isoflavone daidzein, on the other hand, did not demonstrate any significant inhibition of the enzyme activities. At the transcriptional level, DMBA induced the CYP1 enzyme expressions by stimulating the xenobiotic response element (XRE)-dependent transactivation pathway. When genistein $(25 \mu \mathrm{mol} / \mathrm{l})$ was co-administered with DMBA, the XRE-Luc activity the CYP1 mRNA abundances were significantly suppressed. The present study illustrated that the soya isoflavone genistein, but not daidzein, protected against DMBA genotoxicity.
\end{abstract}

Genistein: Isoflavones: Phase I cytochrome P450 enzymes: Dimethylbenz(a)anthracene lesions

Polycyclic aromatic hydrocarbons $(\mathrm{PAH})$ are commonly found in our environment, and they can be isolated from diesel exhaust, barbequed meat, tobacco smoke, overheated cooking oil, etc (International Agency for Research on Cancer, 1983; Environmental Protection Agency, 1990). PAH are metabolized and transformed into DNA-attacking electrophiles in the body. The significance of these environmental toxicants in breast cancer can be inferred from the increased presence of PAH-DNA adducts in human breast tumours (Li et al. 1996).

Aryl hydrocarbon receptor (AHR) is a mediator in the transformation of procarcinogens to genotoxic moieties. After binding to a PAH, the cytosolic AHR translocates to the nucleus and dimerizes with an AHR nuclear translocator. The dimerization initiates transcriptions of a gene containing xenobiotic responsive elements (XRE) in its promoter region (Kronenberg et al. 2000). Cytochrome P450 (CYP) 1A1 and CYP1B1 enzymes, which are responsible for the biotransformation of $\mathrm{PAH}$, are downstream genes of AHR transactivation (Dertinger et al. 2000; Safe, 2001). The importance of AHR and CYP1B 1 enzyme in PAH-induced carcinogenesis is implicated in two gene-knockout mouse results; benzo[a]pyrene (BaP) cannot induce cancer in AHR null mice (Shimizu et al. 2000), and lower cancer incidence was observed in 7,12dimethylbenz[a]anthracene (DMBA)-treated CYP1B1 knockout mice (Buters et al. 1999).

The significance of CYP1 family enzymes in human breast cancer is not clear. Both tumour and normal tissues of the breast express CYP1A1 and CYP1B1 (Spink et al. $1998 a, b$; Iscan et al. 2001). The inhibition of CYP1 enzymes appears to be beneficial in the prevention of DMBA-DNA adduct formation in vivo and in vitro (MacDonald et al. 2001; Kleiner et al. 2002). Polymorphisms with higher activity of CYP1A1 appear to be a risk factor for breast cancer in African-Americans (Taioli, 1999); so are the polymorphisms of CYP1B1 in Asian women (Zheng et al. 2000).

Breast cancer is one of the most common cancers in women. Asian countries have lower breast cancer incidences than the West; however, no difference in breast cancer incidence is found between Asian descendents and other women in America (Ziegler et al. 1993). These results suggest that the environment may play a part in

Abbreviations: AHR, aryl hydrocarbon receptor; BaP, benzo(a)pyrene; CYP, cytochrome P450; DMBA, 7,12-dimethylbenz(a)anthracene; ER, oestrogen receptor; EROD, ethoxyresorufin- $O$-deethylase; $\mathrm{PAH}$, polycyclic aromatic hydrocarbon; PCR, polymerase chain reaction; XRE, xenobiotic response element.

* Corresponding author: Dr Lai K. Leung, fax + 852 26037732, email laikleung@yahoo.com 
the aetiology of breast cancer, and soya consumption has been one of the major leads of investigation. Soya protein (Hakkak et al. 2000), soya extract (Gallo et al. 2001) and the soya isoflavone genistein (Lamartiniere et al. 1995a,b; Fritz et al. 1998, Hilakivi-Clarke et al. 1999) reduce DMBA-induced mammary tumours and mammary gland CYP1 expression (Rowlands et al. 2001) in rats. These data suggest that soya phytochemicals or soya protein could be the active chemopreventive ingredient. However, negative results are also observed for the soya effect on DMBA- (Appelt \& Reicks, 1999) and N-methyl-Nnitrosourea (NMU)- (Cohen et al. 2000) induced mammary carcinogenesis.

The interaction of soya isoflavones and oestrogen receptor (ER) has been a major focus of soya's protective effect on breast cancer. Studies have shown that MCF-7 cells proliferate when exposed to genistein at low micromolar concentrations (Wang \& Kurzer, 1997; Breinholt \& Larsen, 1998; Le Bail et al. 1998; Shao et al. 1998) and experience cell death at higher concentrations (Peterson \& Barnes, 1991; So et al. 1997). These observations have been interpreted as the antagonistic property of genistein to ER in the presence of oestrogen. However, our laboratory (Leung \& Wang, 2000; Po et al. 2002) has demonstrated that the genistein-induced death of MCF-7 cells is not related to the ER antagonistic effect.

Many animal studies have illustrated the protective effect of soya protein or isoflavones against DMBAinduced mammary carcinogenesis, and the mechanism is yet unclear. MCF-7 cells have similar expressions of AHR, CYP1A1 and CYP1B1 to the non-tumour-derived breast epithelial MCF-10A cells (Spink et al. 1998a,b), and MCF-7 cells have the advantages of simpler subculturing conditions and shorter doubling time than MCF-10 cells. With the assumption that XRE transactivation played a pivotal role in PAH genotoxicity, MCF-7 cells are useful in identifying chemopreventive compounds as suggested by Smith et al. (2001). By using this cell culture system, the CYP1 enzyme pathways were investigated at the level ranging from dietary to supplemental intake. It was postulated that genistein and daidzein were modulators of CYP1 enzymes at the transcriptional as well as the enzyme level.

\section{Materials and methods}

\section{Chemicals}

Genistein, daidzein, and DMBA were obtained from Sigma-Aldrich, Milwaukee, WA, USA. Ethoxyresorufin and DMBA were purchased from Sigma Chemicals (St Louis, MO, USA). The carrier solvent dimethyl sulfoxide was also obtained from Sigma Chemicals. All other chemicals, if not stated, were acquired from Sigma Chemicals.

\section{Cell culture}

MCF-7 cells (gift from Dr V. C. Jordan) were cultured in RPMI-1640 phenol red-free media (Sigma Chemicals) and $10 \%(\mathrm{w} / \mathrm{v})$ fetal bovine serum (Invitrogen Life
Technologies, Rockville, MD, USA) at $37^{\circ} \mathrm{C}$ and $5 \%$ (v/v) $\mathrm{CO}_{2}$. Sub-confluent cell cultures were treated with DMBA and various concentrations of genistein or daidzein.

\section{Ethoxyresorufin-O-deethylase activities in intact MCF-7 cells}

The assay method was performed as previously described (Ciolino \& Yeh, 1999). In brief, MCF-7 cells in ninetysix-well plates were treated with $1 \mu \mathrm{M}$-DMBA and various concentrations of genistein or daidzein. The medium was then removed and the cells were washed twice by $100 \mu 1$ PBS. Ethoxyresorufin- $O$-deethylase (EROD) activities, which are indicative of CYP1A1 and CYP1B1, were then carried out. To each well was added $50 \mu \mathrm{l}$ of $5 \mu \mathrm{M}$-ethoxyresorufin in PBS with $1.5 \mathrm{~mm}$-salicyclamide, which was then incubated at $37^{\circ} \mathrm{C}$ for $15 \mathrm{~min}$. The reaction was stopped by $50 \mu \mathrm{l}$ ice-cold methanol, and the resorufin generated was measured by a FLUOstar Galaxy microplate reader (BMG Labtechnologies, Offenburg, Germany) with an excitation of $544 \mathrm{~nm}$ and emission at $590 \mathrm{~nm}$. The activities were quantified against resorufin standards.

\section{Enzyme inhibition assays}

Recombinant CYP1A1 and CYP1B1 expressed in baculovirus-infected insect microsomes (Supersomes ${ }^{\circledR}$ ) were purchased from Gentest Corp., Woburn, MA, USA. Protein ( 2 pmol) was incubated in $100 \mu \mathrm{l}$ PBS, pH 7.2 with $400 \mathrm{nM}-$ ethoxyresorufin and genistein or daidzein in different concentrations. The reaction was initiated by $500 \mu \mathrm{M}-\mathrm{NADPH}$, and stopped by $100 \mu \mathrm{l}$ ice-cold methanol after $20 \mathrm{~min}$ of incubation. The fluorescence was measured as described earlier.

\section{Measurement of cell viability}

Cell viability was assessed by 3-(4,5 dimethylthiazol-2-yl)2,5-diphenyl tetrazolium bromide straining as described by Mosmann (1983). Briefly, MCF-7 cells were plated in ninety-six-well plates at $10^{4}$ cells per well, and $1 \mu \mathrm{M}-$ DMBA and various concentrations of genistein or daidzein were administered for $24 \mathrm{~h}$. At the end of the treatment, $50 \mu \mathrm{l}$ of 3-(4,5 dimethylthiazol-2-yl)-2,5-diphenyl tetrazolium bromide $(1 \mathrm{mg} / \mathrm{ml})$ was added and the cells were incubated at $37^{\circ} \mathrm{C}$ for $4 \mathrm{~h}$. Cell viability was determined by the absorbance at $600 \mathrm{~nm}$.

\section{Measurement of 7,12-dimethylbenz[a]anthracene-DNA adduct formation}

This assay was performed as previously described (Ciolino \& Yeh, 1999). MCF-7 cells were plated in six-well plates at $5 \times 10^{5}$ cells per well and allowed to attach for $24 \mathrm{~h}$. Then $\left[{ }^{3} \mathrm{H}\right] \mathrm{DMBA} \quad(0 \cdot 1 \mu \mathrm{g} / \mathrm{ml} ; \quad$ Amersham, Arlington Heights, IL, USA) was administered with or without genistein or daidzein. After $16 \mathrm{~h}$, cells were washed twice with cold PBS, trypsinized and pelleted. Nuclei were separated by incubating the cells for $10 \mathrm{~min}$ on ice in lysis buffer A (10 mM-tri(hydroxymethyl)-aminomethane- $\mathrm{HCl}, \mathrm{pH} 7 \cdot 5$, $320 \mathrm{~mm}$-sucrose, $5 \mathrm{~mm}$-magnesium chloride and $1 \%$ 
Triton $\mathrm{X}-100)$. The nuclei were collected by centrifugation at $5000 \mathrm{rpm}$ for $10 \mathrm{~min}$ at $4^{\circ} \mathrm{C}$ after the incubation. The nuclei were then lysed by $400 \mu$ l lysis buffer B (1\% (w/v) SDS in $0.5 \mathrm{M}$-tri(hydroxymethyl)-aminomethane, $20 \mathrm{~mm}$-EDTA and $10 \mathrm{~mm}-\mathrm{NaCl}, \mathrm{pH} 9$ ), followed by the treatment of $20 \mu \mathrm{l}$ Proteinase $\mathrm{K}(20 \mathrm{mg} / \mathrm{ml})$ for $2 \mathrm{~h}$ at $48^{\circ} \mathrm{C}$. After that, the samples were allowed to cool to room temperature and the residual protein was salted out by adding $150 \mu \mathrm{l}$ saturated $\mathrm{NaCl}$. The samples were then subjected to centrifugation at $13000 \mathrm{rpm}$ for $30 \mathrm{~min}$ at $4^{\circ} \mathrm{C}$. Genomic DNA was isolated from the supernatant fraction by ethanol precipitation, and redissolved in autoclaved water. Absorbances at 260 and $280 \mathrm{~nm}$ were employed to determine the amount and purity of the extracted DNA. DNA samples that attained a $260 \mathrm{~nm}: 280 \mathrm{~nm}$ ratio of $>1.9$ were used for scintillation counting.

\section{Xenobiotic response element-luciferase gene reporter assay}

Construction of xenobiotic response element-activated luciferase reporter gene. A fragment with five XRE elements from rat CYPIAl 5'-flanking region was amplified from rat genomic DNA as described by Backlund et al. (1997). No other response elements were identified in this fragment. The polymerase chain reaction (PCR) product was digested with SmaI and BamHI and subcloned into a firefly luciferase reporter vector pTA-Luc (Clontech, Palo Alto, CA, USA).

Dual luciferase assays. MCF-7 cells were seeded at $10^{5}$ cells/well in twenty-four-well plates. After $24 \mathrm{~h}$, the cells were transiently transfected with $4.0 \mu \mathrm{g}$ of the XRE reporter plasmid and $1.0 \mu \mathrm{g}$ of renilla luciferase control vector pRL (Promega, Madison, WI, USA) in LipofectAmine (Invitrogen Life Technologies). After $16 \mathrm{~h}$, the medium was removed and the cells were treated with $1 \mu \mathrm{M}$-DMBA and various concentrations of genistein or daidzein for $24 \mathrm{~h}$. The amounts of these two luciferases were determined using Dual-Luciferase Assay Kit (Promega). The luciferase bioluminescence was measured by using a FLUOstar Galaxy plate reader. The XRE transactivation activities represented by firefly luciferase light units were then normalized with that of renilla luciferase.

\section{Semi-quantitative reverse transcription-polymerase chain reaction assay}

A reverse transcription-PCR assay was used to quantify mRNA level. Total RNA was isolated from cells grown in six-well Costar plates in triplicates by a method previously described (Wang \& Phang, 1995). RNA (1 $\mu \mathrm{g})$ was used for cDNA synthesis, and the final volume was diluted to $20 \mu \mathrm{l}$. Primers of CYP1A1, CYP1B1 and $\beta$-actin, sequences as published formerly (Dohr et al. 1995) and a Perkin Elmer Thermocycler (GeneAmp PCR System 2400, Norwalk, CT, USA) were utilized to amplify the target cDNA separately after the first strand reaction. All PCR reactions consisted of dNTP $(0.2 \mathrm{mmol} / \mathrm{l}), 2 \mu \mathrm{l}$ cDNA, primers A and B (both $0.2 \mu \mathrm{mol} / \mathrm{l}$ ), $1 \times \mathrm{PCR}$ buffer and $1 \mathrm{U}$ Taq polymerase. The conditions were $94^{\circ} \mathrm{C}$ for $45 \mathrm{~s}, 65^{\circ} \mathrm{C}$ for $45 \mathrm{~s}, 72^{\circ} \mathrm{C}$ for $1 \mathrm{~min}$, and a final extension period of $7 \mathrm{~min}$ at $72^{\circ} \mathrm{C}$. The amplification cycles were 25 for CYP1A1, 23 for CYP1B1, and 19 for $\beta$-actin. The PCR products were separated on $1.8 \%$ (w/v) agarose gel, stained with ethidium bromide, and photographed. A scanner equipped with Scion Image software (Scion Corporation, Frederick, MD, USA) was used to compare the optical density of the amplified fragments. The linearity of signals was verified in separate experiments.

\section{Statistical methods}

A Prism ${ }^{\circledR} 3.0$ software package (GraphPad Software, Inc., San Diego, CA, USA) was utilized for statistical analysis. The results, whenever applicable, were analysed by oneway ANOVA followed by Bonferroni's multiple comparison test if significant differences $(P<0.05)$ were observed. In order to compare the cell cytotoxicity between DMBAtreated samples and those samples treated with DMBA plus genistein or daidzein, $t$ tests were also performed.

\section{Results \\ Effects of soya isoflavones on 7,12- dimethylbenz[a]anthracene-DNA adduct formation}

To analyse the effects of soya isoflavones on DMBA metabolism, ${ }^{3} \mathrm{H}$-labelled DMBA was added to MCF-7 cells in the presence or absence of isoflavones and the amount of $\left[{ }^{3} \mathrm{H}\right] \mathrm{DMBA}-\mathrm{DNA}$ adduct was measured by scintillation counting. Genistein treatment resulted in a concentration-dependent reduction of $\left[{ }^{3} \mathrm{H}\right] \mathrm{DMBA}-\mathrm{DNA}$ adduct formation (Fig. 1 (A)). However, daidzein did not reduce the adduct formation significantly until a pharmacological concentration of $25 \mu \mathrm{M}$ was reached and the inhibition was minimal (Fig. 1 (B)).

\section{Effect of isoflavones on ethoxyresorufin-O-deethylase activity in MCF-7 cells}

CYP1A1 and CYP1B1 activities were measured as EROD activity in intact cells. DMBA caused approximately a 2-fold increase in EROD activity compared with controls (data not shown). Genistein suppressed this induction in a concentration-dependent manner, with $\mathrm{IC}_{50}$ of approximately $12 \mu \mathrm{M}$ (Fig. 2 (A)). Nevertheless, the suppressive effect of daidzein was far less effective. Only $<30 \%$ of DMBA-induced EROD activity was inhibited by $50 \mu \mathrm{M}-$ daidzein (Fig. 2 (C)). The data indicated that genistein was effective in suppressing DMBA-induced EROD activity. Treatment with the two isoflavones alone only had a slight inhibition on EROD activity in MCF-7 cells (Figs. 2 (B) and 2 (D)).

Kinetic analysis of the inhibition of cytochrome P450 1A1 and 1B1 enzymes by genistein

Because both DMBA-DNA adducts and enzyme activities were decreased in cultures treated with genistein but not daidzein, the inhibition of CYP1A1 and CYP1B1 catalytic 
activities by genistein was further characterized. Since daidzein did not show a significant contribution to the adduct formation and enzyme inhibition, this compound was not pursued any further. Enzyme kinetic experiments using recombinant human CYP1A1 and CYP1B1 enzymes were carried out. The Lineweaver-Burk plots and replots showed that genistein exhibited mixed-type inhibition on CYP1A1 enzyme (Fig. 3 (A)) and competitively inhibited CYP1B1 enzyme (Fig. 3 (B)). Based on the corresponding $\mathrm{K}_{\mathrm{i}}$ values of 15.35 and $0.68 \mu \mathrm{mol} / \mathrm{l}$, genistein appeared to be an effective inhibitor on both CYP1A1 and CYP1B1 activities at physiological concentrations.

\section{Xenobiotic response element-driven luciferase activities}

$\mathrm{MCF}-7$ cells were transfected with an XRE reporter construct and luciferase activity was subsequently measured to reveal AHR-mediated transcription. DMBA induced luciferase activity by more than 5-fold. The addition of
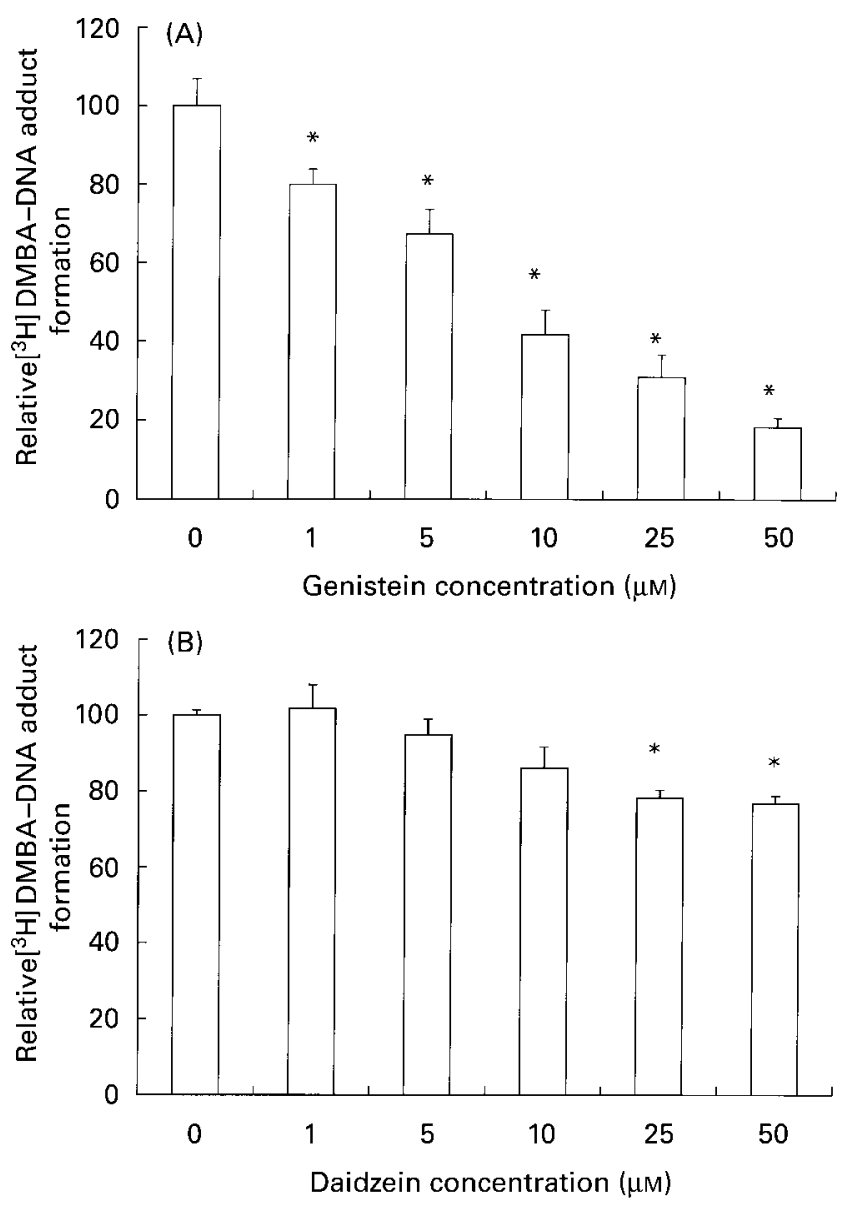

Fig. 1. Effects of isoflavones on 7,12-dimethylbenz[a]anthracene (DMBA)-DNA adduct formation in MCF-7 cells. MCF-7 cells were cultured in six-well plates and treated with ${ }^{3} \mathrm{H}$-labelled DMBA $(0.1 \mu \mathrm{g} / \mathrm{ml})$ and co-administered with soya isoflavones at various concentrations; genistein (A) or daidzein (B). After $16 \mathrm{~h}$ of treatment, genomic DNA was isolated and the DMBA-DNA lesions were determined by scintillation counting. Values are means with their standard errors $(n 3)$. *Mean values were significantly lower than that of the control $(0 \mu \mathrm{M}$-genistein or -daidzein) $(P<0.05)$.
10 and $25 \mu \mathrm{M}$-genistein produced a significant reduction in DMBA-induced luciferase activity (Fig. 4 (A)), while daidzein had no effect at this level (data not shown). By itself, genistein was a weak inducer of the XRE-dependent transactivation (Fig. 4 (B)).
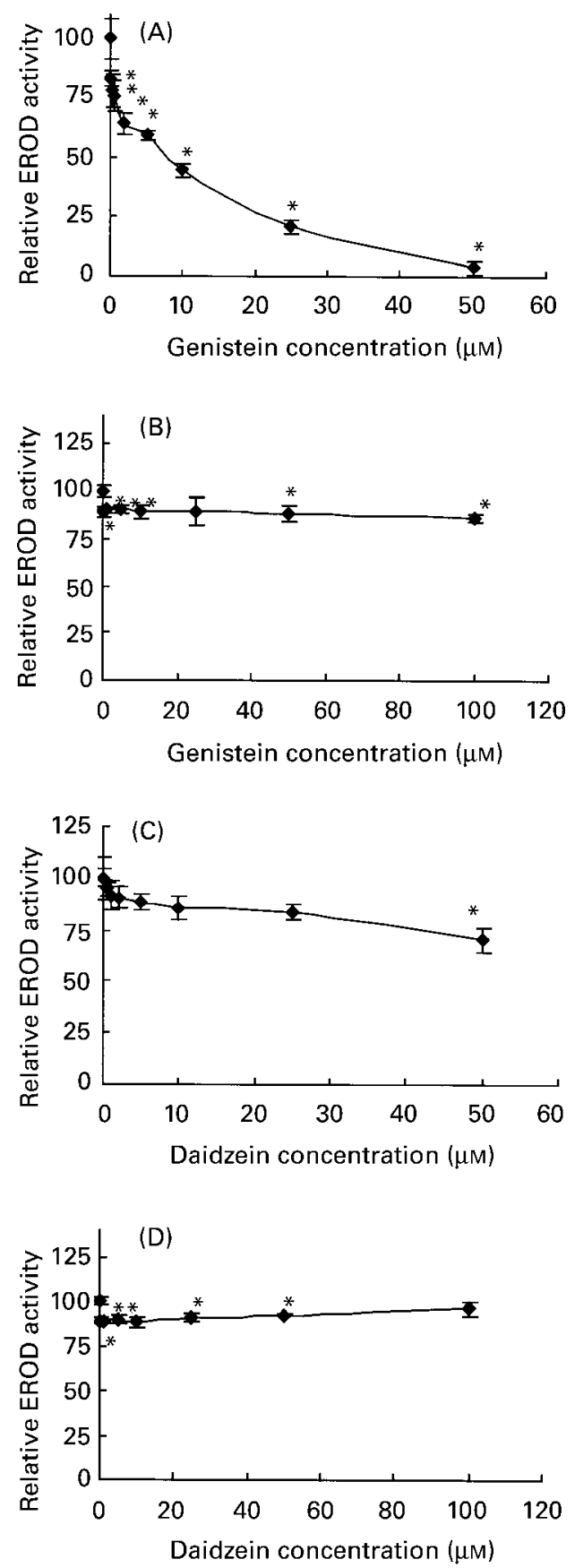

Fig. 2. 7,12-Dimethylbenz[a]anthracene (DMBA)-induced ethoxyresorufin-O-deethylase (EROD) activities in MCF-7 cells treated with soya isoflavones. MCF-7 cells were seeded in ninety-six-well culture plates and treated with $(A$ and $C)$ or without $(B$ and $D) 1 \mu \mathrm{M}-$ DMBA and various concentrations of genistein ( $A$ and $B$ ) and daidzein $(C$ and $D)$. After $24 \mathrm{~h}$ of treatment, cells were assayed for EROD activity as described on p. 458. Values are means with their standard errors $(n 6)$. * Mean values were significantly different from that of the control $(0 \mu \mathrm{M}$-genistein or -daidzein) $(P<0 \cdot 05)$. 

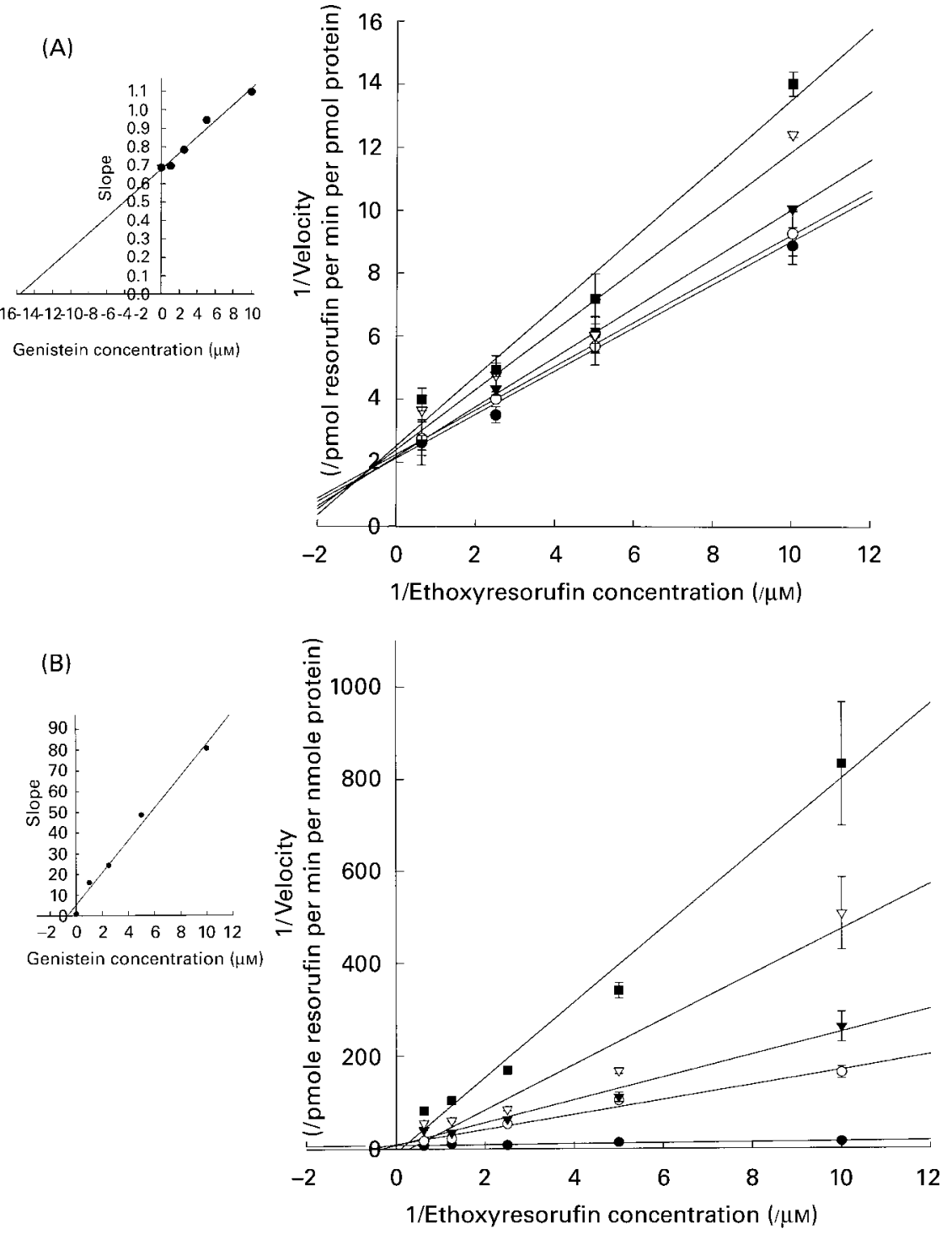

Fig. 3. Lineweaver-Burk plots of genistein on cytochrome P450 (CYP) enzymes CYP1A1 and CYP1B1 inhibition. Ethoxyresorufin-O-deethylase assay was performed with human recombinant CYP1A1 (A) and CYP1B1 (B) at various concentration of genistein $(\bullet), 0 \mu \mathrm{M}$; $\mathrm{O}, 1.0 \mu \mathrm{M}$; $\boldsymbol{\nabla}, 2.5 \mu \mathrm{M} ; \nabla, 5.0 \mu \mathrm{M} ; \boldsymbol{\nabla}, 10 \mu \mathrm{M}$ ) and 100-1600 nM-ethoxyresorufin as described on p. 458. Right, Lineweaver-Burk plots were generated by linear regression of the reciprocal data. Left, replot of the slopes from the Lineweaver-Burk plot, with derivation of $\mathrm{K}_{\mathrm{i}}$. Values shown are means with their standard errors $(n 3)$.

Inhibition of 7,12-dimethylbenz[a]anthracene-induced cytochrome P450 1A1 and 1B1 mRNA levels by isoflavones

Because the XRE-dependent transactivation stimulated by DMBA administration was not affected until $10 \mu \mathrm{mol} / \mathrm{l}$, CYP1A1 and 1B1 gene expressions were also examined to confirm the response. As estimated by the optical density of the images (Fig. 5 (A)), DMBA induced CYP1A1 and CYP1B1 mRNA expressions by 6.6- and 3.1-fold above basal levels, respectively. The increases were abated with genistein co-treatment at the concentration of $25 \mu \mathrm{mol} / 1$ (Figs. 5 (B) and (C)) for both CYP1A1 and CYP1B1. Genistein concentrations at 5 or $10 \mu \mathrm{mol} /$ 1 did not significantly $(P<0.05)$ decrease the mRNA abundance. The observations were consistent with the XRE data.

\section{Discussion}

Previous animal studies (Giri \& Lu, 1995; Fritz et al. 1998) have demonstrated that isoflavones inhibit DMBA-DNA adduct formation, and MCF-7 cells can be a viable model to study the underlying mechanisms (Upadhyaya \& El-Bayoumy, 1998). Making use of this in vitro model, the present study showed that genistein reduced DMBA-DNA adduct formation and the chemopreventive mechanism may be attributed to its interruption of DMBA metabolism. Daidzein, on the other hand, was shown to be non-functional in this regard. Genistein could down regulate CYP1A1 and 1B1 mRNA expressions at $25 \mu \mathrm{mol} / 1$ through its influence on XRE-dependent transcriptional control. At the enzyme level, kinetic studies indicated that the $K_{i}$ values of CYP1A1 and $1 \mathrm{~B} 1$ were 


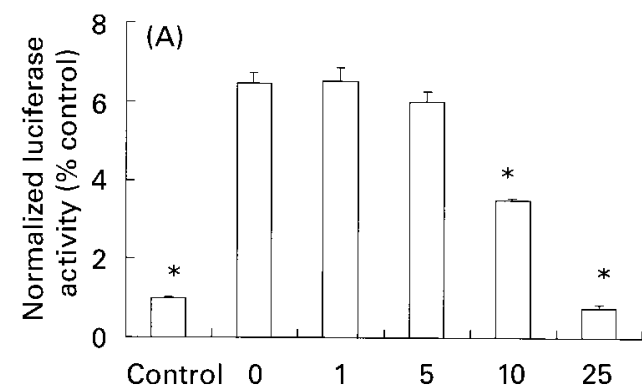

Genistein concentration ( $\mu \mathrm{M}$ )

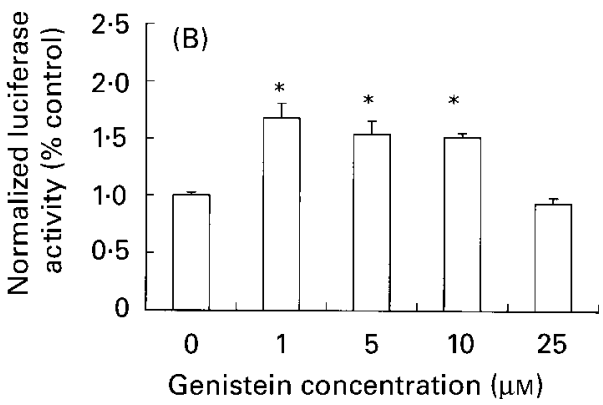

Fig. 4. Effects of genistein on 7,12-dimethylbenz[a]anthracene (DMBA)-induced xenobiotic response element (XRE)-driven luciferase activities. MCF-7 cells were transiently transfected with a luciferase reporter gene containing XRE and a renilla luciferase control plasmid. Genistein was co-administered with (A) or without (B) $1 \mu \mathrm{M}-\mathrm{DMBA}$ for $24 \mathrm{~h}$. Values are means with their standard errors $(n 3)$. ${ }^{*}$ For $(A)$, means were significantly $(P<0.05)$ lower than the cultures treated with DMBA only $(0 \mu \mathrm{M}$-genistein). For (B), means were significantly higher than the control cultures (0 $\mu$ M-genistein).

15.35 and $0.68 \mu \mathrm{mol} / \mathrm{l}$, respectively. Considering that high soya consumption could bring about $0.5 \mu \mathrm{mol}$ genistein/l in blood (Morton et al. 2002), the inhibition at the enzyme level appeared to be more significant than that at the expression level. Moreover, genistein appeared to preferentially inhibit CYP1B1 to CYP1A1 with the consideration of the different $\mathrm{K}_{\mathrm{i}}$ values. In a previous study, the mammary CYP1B1 expression was shown to be higher than that of the liver (Horn et al. 2002). This might imply that the isoflavone could offer a stronger protection of $\mathrm{PAH}$-induced carcinogenesis in the mammary gland than in the liver.

CYP1 enzymes biotransform DMBA, and its metabolites may attack biological macromolecules (Gonzalez \& Gelboin, 1994). In the present study, it was demonstrated that genistein but not daidzein was an inhibitor of human CYP1 at the enzyme as well as at the transcriptional level. In contrast, Shertzer et al. (1999) have shown that both genistein and daidzein competitively inhibit $\mathrm{BaP}$ hydroxylation activities with $\mathrm{IC}_{50}$ of 140 and $325 \mu \mathrm{mol} / 1$ in a mouse hepatoma cell line. BaPDNA adducts are significantly lower in cultures treated with $1 \mathrm{nM}-2,3,7,8$-tetrachlorodibenzo-p-dioxin (TCDD) and $25 \mu \mathrm{M}$-genistein or -daidzein. Helsby et al. (1998) also performed a similar enzyme inhibition study on CYP1A in $\beta$-naphthoflavone-induced mouse liver microsomes, and the $\mathrm{IC}_{50}$ of genistein is in the millimolar
(A) $\quad 1 \mu \mathrm{M}$ DMBA co-treatment
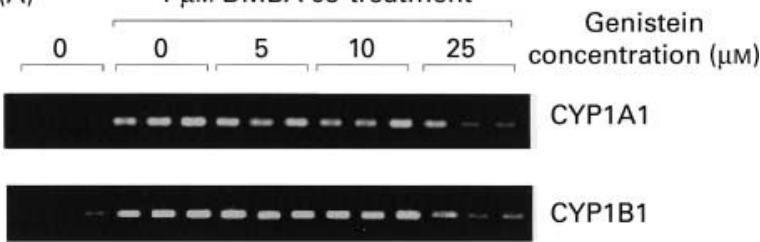

$--0-\infty-\infty-\infty-\infty$ Actin
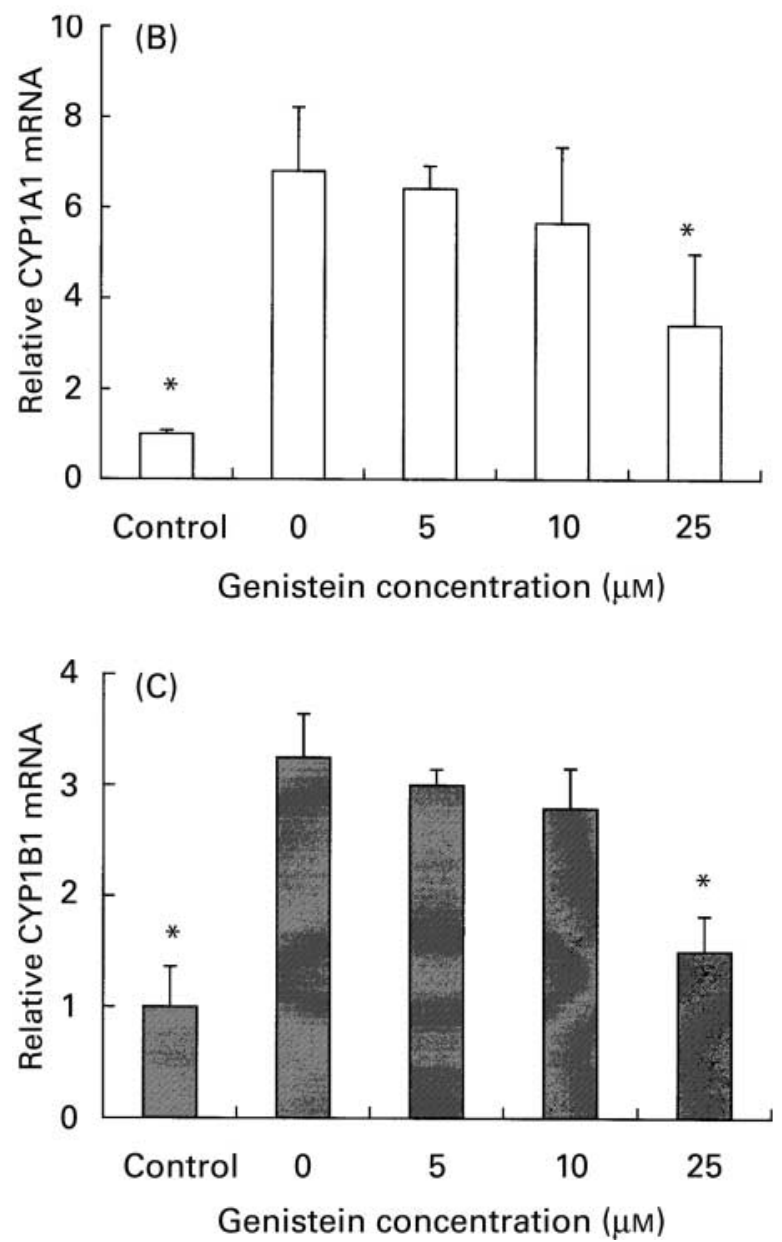

Fig. 5. Effects of genistein on 7,12-dimethylbenz[a]anthracene (DMBA)-induced cytochrome P450 (CYP) enzymes CYP1A1 and CYP1B1 mRNA expression. MCF-7 cells were treated with $1 \mu \mathrm{M}-$ DMBA and genistein, and cultured for $24 \mathrm{~h}$. mRNA expressions of CYP1A1 and CYP1B1 were quantified by reverse transcriptionpolymerase chain reaction (PCR) as described on p. 459. (A), gel image of the ethidium bromide-stained PCR fragments. (B and $C$ ), corresponding optical density results for co-administration with or without $1 \mu \mathrm{M}$-DMBA respectively. Values are means with their standard errors $(n 3)$. *Mean values were significantly $(P<0.05)$ lower than the cultures treated with DMBA only ( $0 \mu \mathrm{M}$-genistein).

range. The TCDD or $\beta$-naphthoflavone administered in these two studies may interfere with subsequent enzyme kinetic and $\mathrm{BaP}-\mathrm{DNA}$ adduct assays, because the residual chemicals remaining in the microsomes can be significant. After all, the differences among those previous studies and the present study could be due to species, cell type, inducer and substrate variations. 
The structure-inhibitory activity relationship has been described in xenobiotic-induced hepatic S9 fraction (Lee et al. 1994). The hydroxyl groups at the $\mathrm{C}^{\prime}$ and $\mathrm{C} 7$ positions of the isoflavone molecules and the phenolic group at C5 are critical for the inhibitory action of EROD (Chae et al. 1992; Lee et al. 1994). As a result, daidzein that has hydroxyl groups at positions $4^{\prime}$ and 7 but lacking a C5 hydroxyl group may not be as active as genistein. The weak enzyme inhibitory effect of daidzein found in the present study was consistent with this structureactivity relationship.

Although AHR activation is a major pathway that controls the transcriptional activity of XRE-containing genes, an alternative AHR-independent mode of transactivation has also been documented (Backlund et al. 1997). In addition, MacDonald et al. (2001) suggest that phytochemicals with similar planar structure as AHR ligands may also act as inducers for CYP1 transcription. The weak induction of genistein on XRE-driven transcriptional activity in the present study may be dependent or independent of AHR activation.

Animal studies have elicited conflicting results on the cancer-protective effect of soya isoflavones. Although prepubertal administration of genistein could reduce breast cancer incidence in rats (Hilakivi-Clarke et al. 2000; Lamartiniere et al. 2002), soya given after weaning appears to be ineffective on DMBA-induced carcinogenesis (Appelt \& Reicks, 1999). In contrast, Gallo et al. (2001) have shown that genistein does not protect DMBA-induced mammary tumour incidence or multiplicity but it reduces the percentage of poorly differentiated tumours. Contradictory to its cancer-protective implication, genistein has been demonstrated to increase DMBA-induced mammary tumours in $\mathrm{ER} \alpha$-intact mice (Day et al. 2001), and encourages the proliferation of MCF-7 tumours in athymic mice (Ju et al. 2001). In a recent study, daidzein and soya protein rather than genistein have been suggested to be the active ingredients in soya that reduce the multiplicity of DMBA-induced mammary tumours in rats (Constantinou et al. 2001). Nevertheless, both daidzein and genistein are effective in delaying the latency of mammary tumour development in a spontaneous carcinogenesis model, although the size and number of tumours are similar at the end of the experiment (Jin \& MacDonald, 2002). These reports appear to be inconsistent regarding the chemopreventive effect of genistein, but the confounding results could be due to the phytochemical's differential actions on the initiation, promotion, and progression stages. The present study illustrated that genistein could be a chemopreventive agent targeting the tumour initiation phase.

The major soya isoflavone metabolite in women is in the glucuronide form, and the aglycone genistein only constitutes about 0.25 of total genistein present in plasma (Zhang et al. 2003). In a high soya-consuming country such as Japan, the average plasma concentration of total genistein is around $0.5 \mu \mathrm{mol} / 1$ in women (Morton et al. 2002). Although the lowest effective concentration (i.e. $1 \mu \mathrm{mol}$ aglycone genistein/l in the present study) may not be achievable purely through dietary intake, it is still possible to reach that concentration by supplementation
(Izumi et al. 2000). In addition, the hormone-responsive tissues have a higher genistein concentration than that of serum (Chang et al. 2000).

In conclusion, the present study identified genistein as the active ingredient in soya that inhibits DMBA-DNA adduct formation. Because CYP1 gene expressions did not alter below $10 \mu \mathrm{mol} / \mathrm{l}$, the inhibition at the enzyme activity level was the mechanism of action in the low concentration range.

\section{Acknowledgements}

This study was supported by the Chinese University of Hong Kong Direct Grant for Research code 2040959. The authors would also like to thank Dr V. C. Jordan for providing the MCF-7 cells.

\section{References}

Appelt LC \& Reicks MM (1999) Soy induces phase II enzymes but does not inhibit dimethylbenz[a]anthracene-induced carcinogenesis in female rats. J Nutr 129, 1820-1826.

Backlund M, Johansson I, Mkrtchian S \& Ingelman-Sundberg M (1997) Signal transduction-mediated activation of the aryl hydrocarbon receptor in rat hepatoma H4IIE cells. J Biol Chem 272, 31755-31763.

Breinholt V \& Larsen JC (1998) Detection of weak estrogenic flavonoids using a recombinant yeast strain and a modified MCF-7 cell proliferation assay. Chem Res Toxicol 11, 622-629.

Buters JT, Sakai S, Richter T, et al. (1999) Cytochrome P450 CYP1B1 determines susceptibility to 7, 12-dimethylbenz[a]anthracene-induced lymphomas. Proc Natl Acad Sci USA 96, $1977-1982$.

Chae YH, Ho DK, Cassady JM, Cook VM, Marcus CB \& Baird WM (1992) Effects of synthetic and naturally occurring flavonoids on metabolic activation of benzo[a]pyrene in hamster embryo cell cultures. Chem Biol Interact 82, 181-193.

Chang HC, Churchwell MI, Delclos KB, Newbold RR \& Doerge DR (2000) Mass spectrometric determination of genistein tissue distribution in diet-exposed Sprague-Dawley rats. J Nutr 130, 1963-1970.

Ciolino HP \& Yeh GC (1999) Inhibition of aryl hydrocarboninduced cytochrome P-450 1A1 enzyme activity and CYP1A1 expression by resveratrol. Mol Pharmacol 56, 760-767.

Cohen LA, Zhao Z, Pittman B \& Scimeca JA (2000) Effect of intact and isoflavone-depleted soy protein on NMU-induced rat mammary tumorigenesis. Carcinogenesis 21, 929-935.

Constantinou AI, Lantvit D, Hawthorne $\mathrm{M}$, Xu X, van Breemen RB \& Pezzuto JM (2001) Chemopreventive effects of soy protein and purified soy isoflavones on DMBA-induced mammary tumors in female Sprague-Dawley rats. Nutr Cancer 41, 75-81.

Day JK, Besch-Williford C, McMann TR, Hufford MG, Lubahn DB \& MacDonald RS (2001) Dietary genistein increased DMBA-induced mammary adenocarcinoma in wild-type, but not ER alpha KO, mice. Nutr Cancer 39, 226-232.

Dertinger SD, Lantum HB, Silverstone AE \& Gasiewicz TA (2000) Effect of $3^{\prime}$-methoxy-4'-nitroflavone on benzo[a]pyrene toxicity. Aryl hydrocarbon receptor-dependent and -independent mechanisms. Biochem Pharmacol 60, 189-196.

Dohr O, Vogel C \& Abel J (1995) Different response of 2,3,7,8tetrachlorodibenzo-p-dioxin (TCDD) - sensitive genes in 
human breast cancer MCF-7 and MDA-MB 231 cells. Arch Biochem Biophys 321, 405-412.

Environmental Protection Agency (1990) Aerometric Information Retrieval System (AIRS), Data for 1985-1990. Washington, DC: Environmental Protection Agency.

Fritz WA, Coward L, Wang J \& Lamartiniere CA (1998) Dietary genistein: perinatal mammary cancer prevention, bioavailability and toxicity testing in the rat. Carcinogenesis 19, 2151-2158.

Gallo D, Giacomelli S, Cantelmo F, et al. (2001) Chemoprevention of DMBA-induced mammary cancer in rats by dietary soy. Breast Cancer Res Treat 69, 153-164.

Giri AK \& Lu LJ (1995) Genetic damage and the inhibition of 7,12-dimethyl-benz[a]anthracene-induced genetic damage by the phytoestrogens, genistein and daidzein, in female ICR mice. Cancer Lett 95, 125-133.

Gonzalez FJ \& Gelboin HV (1994) Role of human cytochromes $\mathrm{P} 450$ in the metabolic activation of chemical carcinogens and toxins. Drug Metab Rev 26, 165-183.

Hakkak R, Korourian S, Shelnutt SR, Lensing S, Ronis MJ \& Badger TM (2000) Diets containing whey proteins or soy protein isolate protect against 7,12-dimethylbenz[a]anthraceneinduced mammary tumors in female rats. Cancer Epidemiol Biomarkers Prev 9, 113-117.

Helsby NA, Chipman JK, Gescher A \& Kerr D (1998) Inhibition of mouse and human CYP1A- and 2E1dependent substrate metabolism by the isoflavonoids genistein and equol. Food Chem Toxicol 36, 375-382.

Hilakivi-Clarke L, Onojafe I, Raygada M, et al. (1999) Prepubertal exposure to zearalenone or genistein reduces mammary tumorigenesis. Br J Cancer 80, 1682-1688.

Horn TL, Reichert MA, Bliss RL \& Malejka-Giganti D (2002) Modulations of P450 mRNA in liver and mammary gland and $\mathrm{P} 450$ activities and metabolism of estrogen in liver by treatment of rats with indole-3-carbinol. Biochem Pharmacol 64, 393-404.

International Agency for Research on Cancer (1983) Polynuclear aromatic compounds, part I, chemical, environmental and experimental data. IARC Monographs on the Evaluation of the Carcinogenic Risk of Chemicals to Human, 32, 1-453.

Iscan M, Klaavuniemi T, Coban T, Kapucuoglu N, Pelkonen O \& Raunio H (2001) The expression of cytochrome P450 enzymes in human breast tumours and normal breast tissue. Breast Cancer Res Treat 70, 47-54.

Izumi T, Piskula MK, Osawa S, et al. (2000) Soy isoflavone aglycones are absorbed faster and in higher amounts than their glucosides in humans. J Nutr 130, 1695-1699.

Jin Z \& MacDonald RS (2002) Soy isoflavones increase latency of spontaneous mammary tumour in mice. J Nutr 132, 3186-3190.

$\mathrm{Ju}$ YH, Allred CD, Allred KF, Karko KL, Doerge DR \& Helferich WG (2001) Physiological concentrations of dietary genistein dose-dependently stimulate growth of estrogen-dependent human breast cancer (MCF-7) tumors implanted in athymic nude mice. J Nutr 131, 2957-2962.

Kleiner HE, Vulimiri SV, Reed MJ, Uberecken A \& DiGiovanni J (2002) Role of cytochrome P450 1a1 and 1b1 in the metabolic activation of 7,12-dimethylbenz-[a]anthracene and the effects of naturally occurring furanocoumarins on skin tumor initiation. Chem Res Toxicol 15, 226-235.

Kronenberg S, Esser C \& Carlberg C (2000) An aryl hydrocarbon receptor conformation acts as the functional core of nuclear dioxin signaling. Nucleic Acids Res 28, 2286-2291.

Lamartiniere CA, Cotroneo MS, Fritz WA, Wang J, Mentor-Marcel R \& Elgavish A (2002) Genistein chemoprevention: timing and mechanisms of action in murine mammary and prostate. J Nutr 132, 552S-558S.

Lamartiniere CA, Moore J, Holland MB \& Barnes S (1995a)
Neonatal genistein chemoprevents mammary carcinogenesis. Proc Soc Exp Biol Med 208, 120-123.

Lamartiniere CA, Moore JB, Brown NM, et al. (1995b) Genistein suppresses mammary cancer in rats. Carcinogenesis 16, 2833-2840.

Le Bail JC, Varnet F, Nicolas JC \& Habrioux G (1998) Estrogenic and anti-proliferative activities on MCF-7 human breast cancer cells by flavonoids. Cancer Lett 130, 209-216.

Lee H, Wang HW, Su HY \& Hao NJ (1994) The structureactivity relationships of flavonoids as inhibitors of cytochrome p-450 enzymes in rat liver microsomes and the mutagenicity of 2-amino-3-methyl-imidazo[4,5-f]quinoline. Mutagenesis 9, $101-106$.

Leung LK \& Wang TT (2000) Bcl-2 is not reduced in the death of MCF-7 cells at low genistein concentration. J Nutr 130, 2922-2926.

Li D, Wang M, Dhingra K \& Hittelman WN (1996) Aromatic DNA adducts in adjacent tissues of breast cancer patients: clues to breast cancer etiology. Cancer Res 56, 287-293.

MacDonald CJ, Ciolino HP \& Yeh GC (2001) Dibenzoylmethane modulates aryl hydrocarbon receptor function and expression of cytochromes P50 1A1, 1A2, and 1B1. Cancer Res 61, 3919-3924.

Morton MS, Arisaka O, Miyake N, Morgan LD \& Evans BAJ (2002) Phytoestrogen concentrations in serum from Japanese men and women over forty years of age. J Nutr 132, $3168-3171$.

Mosmann T (1983) Rapid colorimetric assay for cellular growth and survival: application to proliferation and cytotoxicity assays. J Immunol Methods 65, 55-63.

Peterson G \& Barnes S (1991) Genistein inhibition of the growth of human breast cancer cells: independence from estrogen receptors and the multi-drug resistance gene. Biochem Biophys Res Commun 179, 661-667.

Po LS, Wang TT, Chen ZY \& Leung LK (2002) Genisteininduced apoptosis in MCF-7 cells involves changes in Bak and Bcl-x without evidence of anti-oestrogenic effects. $\mathrm{Br} \mathrm{J}$ Nutr 88, 463-469.

Rowlands JC, He L, Hakkak R, Ronis MJJ \& Badger TM (2001) Soy and whey proteins downregulate DMBA-induced liver and mammary gland CYP1 expression in female rats. J Nutr 131, 3281-3287.

Safe S (2001) Molecular biology of the Ah receptor and its role in carcinogenesis. Toxicol Lett 120, 1-7.

Shao ZM, Alpaugh ML, Fontana JA \& Barsky SH (1998) Genistein inhibits proliferation similarly in estrogen receptor-positive and negative human breast carcinoma cell lines characterized by $\mathrm{p} 21 \mathrm{WAF} 1 / \mathrm{CIP} 1$ induction $\mathrm{G} 2 / \mathrm{M}$ arrest and apoptosis. $J$ Cell Biochem 69, 44-54.

Shertzer HG, Puga A, Chang C, et al. (1999) Inhibition of CYP1A1 enzyme activity in mouse hepatoma cell culture by soybean isoflavones. Chem Biol Interact 123, 31-49.

Shimizu Y, Nakatsuru Y, Ichinose M, et al. (2000) Benzo[a]pyrene carcinogenicity is lost in mice lacking the aryl hydrocarbon receptor. Proc Natl Acad Sci USA 97, 779-782.

Smith WA, Freeman JW \& Gupta RC (2001) Effect of chemopreventive agents on DNA adduction induced by the potent mammary carcinogen dibenzo[a,1]pyrene in the human breast cells MCF-7. Mutat Res 480-481, 97-108.

So FV, Guthrie N, Chambers AF \& Carroll KK (1997) Inhibition of proliferation of estrogen receptor-positive MCF-7 human breast cancer cells by flavonoids in the presence and absence of excess estrogen. Cancer Lett 112, 127-133.

Spink BC, Fasco MJ, Gierthy JF \& Spink DC (1998a) 12-O-tetradecanoylphorbol-13-acetate upregulates the $\mathrm{Ah}$ receptor and differentially alters CYP1B1 and CYP1A1 expression in MCF-7 breast cancer cells. J Cell Biochem 70, 289-296. 
Spink DC, Spink BC, Cao JQ, et al. (1998b) Differential expression of CYP1A1 and CYP1B1 in human breast epithelial cells and breast tumor cells. Carcinogenesis 19, 291-298.

Taioli E (1999) International collaborative study on genetic susceptibility to environmental carcinogens. Cancer Epidemiol Biomarkers Prev 8, 727-728.

Upadhyaya P \& El-Bayoumy K (1998) Effect of dietary soy protein isolate, genistein, and 1,4-phenylenebis(methylene)selenocyanate on DNA binding of 7,12-dimethyl-benz[a]anthracene in mammary glands of $\mathrm{CD}$ rats. Oncol Rep 5, $1541-1545$

Wang C \& Kurzer MS (1997) Phytoestrogen concentration determines effects on DNA synthesis in human breast cancer cells. Nutr Cancer 28, 236-247.

Wang TT \& Phang JM (1995) Effects of estrogen on apoptotic pathways in human breast cancer cell line MCF-7. Cancer Res 55, 2487-2489.

Zhang Y, Hendrich S \& Murphy PA (2003) Glucuronides are the main isoflavone metabolites in women. $J$ Nutr 133, 399-404.

Zheng W, Xie DW, Jin F, et al. (2000) Genetic polymorphism of P450 1B1 and risk of breast cancer. Cancer Epidemiol Biomarkers Prev 9, 147-150.

Ziegler RG, Hoover RN, Pike MC, et al. (1993) Migration patterns and breast cancer risk in Asian-American women. $J$ Natl Cancer Inst 85, 1819-1827. 